\title{
Military history a century after the Great War
}

L'histoire militaire un siècle après la Grande Guerre

\section{William Philpott}

\section{OpenEdition}

\section{Journals}

Electronic version

URL: http://journals.openedition.org/rfcb/288

DOI: $10.4000 /$ rfcb.288

ISSN: 2429-4373

\section{Publisher}

CRECIB - Centre de recherche et d'études en civilisation britannique

\section{Printed version}

Date of publication: 15 January 2015

ISSN: 0248-9015

\section{Electronic reference}

William Philpott, "Military history a century after the Great War », Revue Française de Civilisation Britannique [Online], XX-1 | 2015, Online since 01 May 2015, connection on 19 April 2019. URL : http:// journals.openedition.org/rfcb/288; DOI : 10.4000/rfcb.288

This text was automatically generated on 19 April 2019

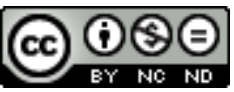

Revue française de civilisation britannique est mis à disposition selon les termes de la licence Creative Commons Attribution - Pas d'Utilisation Commerciale - Pas de Modification 4.0 International. 


\title{
Military history a century after the Great War
}

\author{
L'histoire militaire un siècle après la Grande Guerre
}

William Philpott

1 The parameters and issues of British military history of the First World War were largely set in the war's immediate aftermath. By the 1930s soldiers and statesmen had argued the pros and cons of Britain's strategy of 'continental commitment' - raising a mass citizen army to fight in France and Flanders alongside Britain's French ally, rather than pursuing a more traditional maritime strategy. Since the 1960s the men who went to war have been studied by social and cultural historians, although how they made war has only recently become a trend in historiography. The military conduct of the land campaigns, especially that on the western front, was also subject to scrutiny before the archive were opened in the 1960s, largely by popular historians. ${ }^{1}$ To a great extent by the 1980s Britain's war experience had become lost amid well-established cultural myths of the conflict: Dan Todman has examined the nature and import of such myths, of command incompetence, mud, futility and mass death. ${ }^{2}$ Historians' effort thereafter was focused on explaining the practicalities of adapting the British army to the demands of modern warfare, and the constraints upon British strategy. A century after the war British military history is only now starting to break out of the parochial channels steered since the 1930s. The constraints of coalition war and comparative studies of military performance are emerging as the new historical paradigms for understanding the British experience of warfare between 1914 and 1918.

2 For several decades military historians in Britain have been re-examining myths and misperceptions about the British army's effectiveness on the battlefield. This is a largely monographic literature, which has yet to be synthesised into a narrative of British military performance in the war. This historical revisionism began with the identification and consideration of the concept of a 'learning curve' of improving British military performance from the army's early and costly trench battles of 1915 and 1916, Loos and the Somme, to the successful British advance and defeat of the German army in $1918 .{ }^{3}$ While the concept of a learning curve is now considered too simplistic, studying the 
process by which the British army adapted to modern industrialised warfare has been the predominant trend in Anglophone military history of the war since the 1990s. The focus has been primarily on the western front, and the period of trench warfare, although imperial forces and extra-European campaign have also been studied. ${ }^{4}$

3 An over-simplified, negative view of British military effectiveness in the First World War emerged from the counter-cultural landscape of 1960s Britain. A lone voice, the journalist John Terraine, attempted to present the British army, and its leader Douglas Haig in particular, in a more nuanced and favourable light by placing the army's efforts firmly in the context of the rapid and complex changes in warfare taking place between 1914 and 1918..$^{5}$ While Terraine's essentially popular history was limited in its source base and range, it inspired scholars such as Paddy Griffith, Brian Bond, Peter Simkins and John Bourne to look again at the British army's military practices and actions. ${ }^{6}$ Early contributors from the Commonwealth set the parameters of the debate: the Canadian historian Tim Travers suggested an army hidebound by Edwardian social conventions and slow to adapt, while the Australians Robin Prior and Trevor Wilson in their groundbreaking study of General Sir Henry Rawlinson as a military commander suggested a general and an army that adapted slowly and traumatically to the challenges presented by the modern battlefield. ${ }^{7}$ British historians have been less harsh in their judgments. Douglas Haig has remained the focus of attention, not least because he remains a misunderstood public hate figure despite repeated analysis both of his personality and methods as a field commander. While far from faultless, both John Paul Harris and Gary Sheffield have explained the army which Haig led and the problems of command that he negotiated with greater critical balance. ${ }^{8}$ At the same time, broader studies of the command culture and practices of the British army, as well as biographical studies of its leaders, have developed understating of it as a military institution. ${ }^{9}$

In recent years the focus of scholarship has moved away from the men who ran the army and towards the way the army operated. As well as Andy Simpson's collective study of Army Corps commanders cited above, which elaborated the key level of operation command and the systems with which the army worked on the battlefield, other important monographs have investigated the logistics of the British army and more recently its communications and intelligence systems. ${ }^{10}$ Echoing a trend in the study of armed forces more generally, the most recent tendency, which has yet to produce definite findings, has been to examine the processes of institutional learning and adaptation that allowed the army to rise to the challenges of modern war. The outcomes have been suggested in Jonathan Boff's recent monograph on the British Third Army in 1918, which explains why the British army was able to defeat the German army on the battlefield. ${ }^{11}$ Boff's highly original study using documentary sources and quantitative methods not only applies the developing understanding of the British army's effectiveness to a battlefield case study, but also pioneers a comparative methodology that aids understanding of processes and outcomes on the battlefield. Boff's study complements more sociological studies of the experience of the opposing armies such as Alex Watson's comparative study of British and German military morale..$^{12}$ More focused battle studies, such as this author's multi-national study of the 1916 Somme offensive, point the way forward towards a nuanced understanding of First World War warfare and how the societies that waged it engaged with its challenges. A greater appreciation of the impact of the home front on processes and outcomes on the battlefield needs to be developed however, so that modern warfare can be seen in the round. 
5 Strategy remains a field of investigation and growing consensus. The old (and largely counter-factual) controversies set up by the war's protagonists - between 'easterners' and 'westerners' essentially, over whether effort should have been concentrated on defeating the German army on the western front or might have been more effectively employed in other theatres - have been increasingly rejected as a useful framework for understanding the complexities of Great War strategy. In two important volumes on strategic policy, David French refocused the study of strategy on the complex relationship between government departments (and their ministers) and competing demands on finite resources, suggesting that strategy involved a great deal more than the movement of armies and navies. ${ }^{13}$ How these department actually made war, however, remains unclear and is developing as a subject for fuller investigation. Slipping back into the east versus west dialectic, Brock Millman challenged French's conception that a push to victory determined strategy under Lloyd George's leadership, suggesting instead that increasing pessimism that the war could be won diverted the Prime Minster's attention away from beating German in the west as his generals always advocated towards defending the British empire in the east after $1917 .{ }^{14}$ These interpretations, to which Nicholas Lambert recently added a detailed study of the flawed strategy of 'economic warfare' in 1914 and 1915 , suggests that the components and objective of wartime strategy are still being established. ${ }^{15}$

6 The most fruitful area of strategic studies in recent years has been that of coalition warfare. Developing from earlier studies of 'national' strategy, recent scholarship has demonstrated that Britain made war in alliance, and that Britain's strategic choices were constrained by the policies and needs of France, Russia, Italy and the United States, as well as her own strategic imperative of holding the alliance together. Ranging from the theme of coordination of military operations on the land fronts through wider questions of resource coordination and allocation, finance and coalition management, such studies have brought out more fully Britain's place in a world war, and her role - important but often subordinate - in the running of a military alliance. ${ }^{16}$ Surprisingly, in the field in which Britain contributed most to the alliance, that of maritime strategy, there are as yet no studies that bring out the coalition nature of the naval war effort. As the war's centenaries pass, more rounded views of allied strategy and war making should emerge.

7 Over recent decades historical understanding of the nature and practices of the British army between 1914 and 1918 has developed profoundly from the broad-based battle studies that characterise traditional military history. Now the concepts and conclusion from this transformation of our understanding of the military effectiveness of the British army are starting to inform recent battle studies. ${ }^{17}$ Whether the achievements of British armed forced in the First World War will now be publicly acknowledged, however, remains to be seen. Anglophone scholars are now applying their methodology to other armies. Robert Foley, Tim Gale and Jonathan Krause are making their names as experts on the armies of Germany and France, in the absence of a strong academic military history tradition in those countries' universities. ${ }^{18}$ The history of armies and warfare remains a strong trend in British First World War studies. The many recent monographs based on doctoral research will be supplemented by further in-depth studies as the centenaries pass. All this points towards a trans-national comparative approach based on British methodologies as the way forward for developing knowledge and understanding of the nations that went to war and the changing nature of warfare between 1914 and 1918. 
Even before the formal commemorations have begun, it is clear that the centenaries of the First World War will be a major public event in Great Britain, one with which profession historians must engage. A series of national and international commemorative events has been announced by the British government, alongside a funded programme of local community projects. ${ }^{19}$ The Imperial War Museum has taken on a coordinating role for public commemoration, and has just launched a 'Lives of the First World War' crowdsourcing project to identify the roles played by individuals during the conflict. ${ }^{20}$ This has the potential to refocus public understanding away from a prevailing obsession with the trenches and towards a wider understanding of the national community's engagement with the war, as well as its global scale and issues. The BBC has commenced a four-year season of Great War related programming, even before the actual centenaries are upon us. ${ }^{21}$ Other broadcasters are no doubt finalising their centenary output, while publishers are printing and reprinting historical and literary works on First World War themes. The war certainly remains a living war in Britain and the centenary commemorations are starting with a bang. Whether public interests will be stimulated or quickly satiated, and whether this generates light or merely heat remains to be seen.

The centenaries represent a brilliant opportunity for historians of the war - never has a series of familiar yet now increasingly distant and alien events had the potential to capture the public imagination, or to benefit from such prolonged exposure. With no surviving veterans to compel society along narrow, familiar commemorative paths, moreover, this will be the historians' centenary. Looking at the first wave of media-driven history, however, the opportunity for presenting up-to-date knowledge and understanding has yet to come. The media frenzy began in late 2013, with new books on the origins and early months of the war (plus a few on later aspects and on the war as whole) and a wide range of original and repeated television and radio progammes: more will follow through 2014 and afterwards. Already the centenaries are generating public controversy. The government's programme of commemorative events has provoked criticism in the historical community, dwelling as it does on the familiar 'tragic' reference points of the war - August 1914, Gallipoli, the Somme and Passchendaele - thereby accentuating the negatives rather than balancing these with positives such as the impressive series of military victories that ended the war. Other communities have questioned why the war's centenaries are being marked at all. One thing that historians are emphasising is the parallels between the First World War and the supposedly 'good' second World War which followed it, both in its purpose and its conduct. Political correctness, and an unwillingness to offend European partners, nevertheless threatens to sublimate reengagement with the genuine issues over which the war was fought into a Europe-wide 'peace fest' as commemoration becomes a trans-national activity. It remains the historians' role to explain the issues of wartime in the terms understood by its protagonists and to resist the tyranny of modern sensibilities that may produce another misreading of the conflict similar to that which developed from its fiftieth anniversaries.

In Britain it is the big celebrity names who have had the first word - the journalist Max Hastings on 1914 and the broadcaster Jeremy Paxman on Britain's war, with the inevitable TV series and book tie-in. ${ }^{22}$ Historians are not yet despairing of the media's approach to the commemorations, but they are also concerned about the place of serious historical scholarship amid growing 'infotainment' about the war, and whether recent insight will be swamped by thoughtless rehashing of discredited interpretations or checked by a growing 'war weariness' in time. From the BBC's early programming it 
seems that radio and niche television channels will broadcast programmes with scholarly content, while mainstream channels will dramatise historical events such as the July crisis and offer First World War themed entertainment such as dramas and literary adaptations.

It is becoming clear that professional historians will not front the centenary presentation of the war, and at best will operate only on its margins, as historical advisers and talking heads. But they will be active behind the scenes and over five years they have an excellent opportunity to expand the range of interest and understanding of the war, and to help to correct outdated or misconceived impressions. Scholars need to step out of the lecture theatre and to engage with the public - new media and old give historians an unprecedented opportunity to communicate. It is unlikely (although not impossible) that recent reinterpretations of the war will prevail come 2018, although the presentation of an alternative viewpoint will show that the war remains a contested and evolving historical phenomenon. The historical landscape will be shaped for the next twenty-five to fifty years: it will look very different from that which was established in the days before serious academic scholarship on the war, which effectively commenced in the 1960s after British national archives were opened. Scholarship and historiographical debates have also broken out of the parameters established by the war generation. New interpretations and original subjects will be brought to the public's attention. The shock troops of the British Commission for Military History, the International Society for First World War Studies and other interested professional organisation are gearing up for five years of sustained engagement with fellow scholars, leaders, teachers and the public. ${ }^{23}$ If professional historians can look beyond the trenches, present the issues of 1914-18 clearly and cogently, and explain the nature and impact of warfare on home and fighting fronts we will have established the war as a determining historical event, while not denying its significance as a cultural phenomenon whose memory and history shifts with each generation's reengagement with the conflict and its outcomes. If we move understanding of the war out of the trenches and towards a rounded picture of societies waging modern war for global stakes, then historians will have achieved something from the centenaries.

\section{ENDNOTES}

1. For an assessment of the state of the discipline before the recent phase of revisionism see B.J. Bond (ed.), The First World War and British Military History (Oxford: The Clarendon Press, 1991)

2. D. Todman, The First World War: Myth and Memory (London: Hambledon, 2005)

3. An early attempt to present these findings more widely can be found in G. Sheffield, Forgotten Victory: The First Word War, Myths and Realities (London: Review, 2001)

4. See for example, M. Hughes, Allenby and British Strategy in the Middle East (London: Routledge, 1999)

5. Most notably in J. Terraine, Douglas Haig: The Educated Solider (London: Hutchinson, 1963) and White Heat: The New Warfare, 1914-1918 (London: Sidgwick and Jackson, 1982) 
6. P. Griffith, Battle Tactics of the Western Front: The British Army's Art of Attack, 1916-18 (New Haven, Ct. Yale UP, 1994) and (ed.), British Fighting Methods in the Great War (London: Frank Cass, 1996)

7. T. Travers, The Killing Ground: The British Army, the Western Front and the Emergence of Modern Warfare, 1900-1918 (London: Unwin Hyman, 1987) and How the War Was Won: Command and Technology in the British Army on the Western Front (London: Routledge, 1992); R. Prior \& T. Wilson, Command on the Western Front: The Military Career of Sir Henry Rawlinson, 1914-18 (Oxford: Blackwell, 1992)

8. B.J. Bond \& N. cave (eds), Haig: A Reappraisal 70 Years On (Barnsley: Leo Cooper, 1999;

G. Sheffield \& J. Bourne, Douglas Haig: War Diaries and Letters, 1914-1918 (London: Weidenfeld \& Nicholson, 2005); J. P. Harris, Douglas Haig and the First World War (Cambridge: Cambridge University Press, 2008); Gary Sheffield, The Chief: Douglas Haig and the British Army (London: Aurum, 2011)

9. S. Robbins, British Generalship on the Western Front, 1914-1918: Defeat into Victory (London: Frank Cass, 2005) \& British Generalship During the Great War: The Military Career of Sir Henry Horne (1861 1929) (Farnham: Ashgate 2010); A. Simpson, Directing Operations: British Corps Command on the Western Front (Staplehurst: Spellmount, 2006); G. Sheffield and D. Todman, Command and Control on the Western Front: The British Army's Experience, 1914-18 (Staplehurst: Spleelmount, 2007); I. Beckett and S. Corvi (eds), Haig's Generals (Barnsley: Pen \& Sword, 2009)

10. I. M. Brown, British Logistics on the Western Front (Westport, Ct: Praeger, 1998), J. Beach, Haig's Intelligence: GHQ and the German Army, 1916-1918 (Cambridge: Cambridge University Press, 2013)

11. J. Boff, Winning and Losing on the Western Front: The British Third Army and the Defeat of Germany (Cambridge: Cambridge University Press, 2012).

12. A. Watson, Enduring the Great War: Combat, Morale and Collapse in the German and British Armies, 1914-1918 (Cambridge: Cambridge UP, 2009)

13. David French, British War Aims and Strategy, 1914-1916 (London: Allen \& Unwin, 1986) and The Strategy of the Lloyd George Coalition (Oxford: Clarendon Press, 1995)

14. B. Millman, Pessimism and British War Policy, 1916-18 (London, Frank Cass, 2001)

15. N. Lambert, Facing Armageddon: British Economic Warfare and the First World War (Cambridge MA: Harvard University Press, 2012)

16. K. Neilson, Strategy and Supply: The Anglo-Russian Alliance, 1914-1917 (London: Harper Collins, 1984) W. Philpott, Anglo-French Relation and Strategy on the Western Front, 1914 - 1918 (London: Macmillan, 1996); Cassar, The Forgotten Front: The British Campaign in Italy, 1917-18 (London: Hambledon Press, 1998); E. Greenhalgh, Victory Through Coalition: Britain and France During the First World War (Cambridge: Cambridge UP, 2005)

17. For Example, N. Lloyd, Hundred Days: The End of the Great War (London: Viking, 2013)

18. R. Foley, German Strategy and the Path to Verdun: Erich von Falkenhayn and the Development of Attrition, 1870-1916 (Cambridge: Cambridge University Press; T. Gale, The French Army' Tank Force and Armoured Warfare in the Great War: The Artillerie Spéciale (Farnham: Ashgate, 2013); J. Krause, Early Trench Tactics in the French Army: The Second Battle of Artois, May-June 1915 (Farnham: Ashagte, 2013)

19. https://www.gov.uk/government/topical-events/first-world-war-centenary

20. http://www.iwm.org.uk/centenary

21. http://www.bbc.co.uk/ww1

22. Max Hastings, Catastrophe: Europe Goes to War, 1914 (London: William Collins, 2013); J. Paxman, Great Britain's Great War (London: Viking, 2013)

23. http://www.bcmh.org.uk/index.php; http://www.firstworldwarstudies.org 
AUTHOR

WILLIAM PHILPOTT

King's College London 